\title{
Does spirituality correlate with students' empathy during Covid-19 pandemic? the case study of Indonesian students
}

\author{
Fifi Khoirul Fitriyah ${ }^{\left.1^{*}\right)}$, Nopriadi Saputra ${ }^{2}$, Maretha Dellarosa ${ }^{3}$, Wiwik Afridah ${ }^{1}$ \\ ${ }^{1}$ Universitas Nahdlatul Ulama Surabaya, Indonesia \\ ${ }^{2}$ Bina Nusantara University, Indonesia \\ ${ }^{3}$ The Ohio State University, Amerika Serikat \\ ${ }^{*}$ Corresponding author, $\equiv$ e-mail: fifi@unusa.ac.id
}

\begin{abstract}
Covid-19 pandemic has affected all parts of human life. It affects health, as well as socio and economic aspects. In this situation, high empathy should follow the implementation of physical distancing to reduce the spread of the virus. However, anti-social behavior has mostly materialized. This study aims to explore the spiritual effect on students' empathy during the Covid-19 pandemic. It observes if spirituality predicts empathy and the other way around. 1004 university students from 65 universities in East Java, Indonesia, were recruited to give responses from a set of questionnaires. Smart-PLS application was used to analyze the statistical data. Findings uncovered that this measurement model is valid and reliable for spirituality (Spiritual Assessment Scale=SAS) and empathy (Interpersonal Reactivity Index=IRI) construct. Through a structural model, our study also found that spirituality and empathy have a significant reciprocal relationship (with a path coefficient of 0.564 ). Spirituality predicts empathy and the other way around. Our findings suggest that universities' counseling units apply spiritual strategies in counseling activities to accelerate students' empathy during the Covid-19 pandemic and to anticipate the future crisis.
\end{abstract}

Keywords: Counseling, covid-19, empathy, spirituality.

How to Cite: Fitriyah, F., Saputra, N., Dellarosa, M., \& Afridah, W. (2020). Does spirituality correlate with students' empathy during covid-19 pandemic? the case study of Indonesian students. COUNS-EDU: The International Journal of Counseling and Education, 5(3). 125-135. DOI: http://dx.doi.org/10.23916/0020200527820

This is an open access article distributed under the Creative Commons Attribution License, which permits unrestricted use distribution, and reproduction in any medium, provided the original work is properly cited. (C2020 by author.

\section{Introduction}

Covid-19 pandemic has become a world tragedy, including in Indonesia. It has affected all human life aspects, from physical to mental health (Lee \& Morling, 2020; C. Liu et al., 2020; Pfattheicher et al., 2020). Humanitarian tragedies also occur, ranging from the rejection of the bodies of Covid-19 victims that occurred in several regions in Indonesia, to anti-social attitudes that are increasingly apparent when there are individuals who need help. Some media reports say that many accident victims have been displaced because people are afraid to help. In addition, efforts to isolate and discriminate against Covid-19 patients and their families in the community further aggravate the situation (Azanella, 2020). Such situations indicate a high incidence of lack of empathy and have an impact on the pandemic situation.

Humanitarian tragedies also occur, ranging from the rejection of the bodies of Covid-19 victims that occurred in several regions in Indonesia, to anti-social attitudes that are increasingly apparent when there are individuals who need help. Some media reports say that many accident victims have been displaced because people are afraid to help. Recent research says that empathy is related to humor, and humor can be positively or negatively correlated, it depends on the implementation of behavior (Halfpenny \& Amelia, 2020). Recently, the phenomenon occurred in Indonesia. It was horrified by the negative behavior of the 
YouTubers who carried out acts of food distribution that actually it was garbage just to increase viewers and subscribers. This action was condemned by the community and is currently being handled legally by the police (Riandi, 2020). If it based on research analysis, The YouTuber's behavior is an act of aggressive humor that is negatively correlated with empathy and affective sympathy (Halfpenny \& Amelia, 2020).

Empathy refers to the ability to come to other people's reference structures and perceive what they feel (Rogers, 1956). Recent research reveals the importance of empathy in increasing creativity, so it can be concluded that social aspects including empathy, are one component in creativity (Form \& Kaernbach, 2018). Regarding the Callous-Unemotional (CU) trait, empathy negatively correlates with cognitive and emotional aspects (Lethbridge et al., 2017). It means that prosocial attitude is the essence of empathy. Research shows that altruistic behavior arises in various social situations that are in line with multiple theories that cause such reactions (Farrelly et al., 2015).

Previous studies state that spirituality is closely related to empathy both directly and indirectly in students population (Giordano et al., 2014; Lal et al., 2020; Moloney \& Gair, 2015). But on the other hand, some research results suggest that spiritual dimensions are not proven to be able to predict empathy (Markstrom et al., 2010; Stewart et al., 2018). So, research between the two constructs needs to be further investigated using representative samples and more precise operational definitions.

Each of the spiritual dimension has its meaningful definition. The term of spiritual becomes a consensus of an alternative to illustrate a transcendent in these late decades. This term has various definitions depending on the values within the cultural group, nationality, and religion (Nelson, 2009). However, nowadays, some people perceive that spirituality and religion have the same definition (Vachon, Fillion, \& Achille, 2009; Albers et al., 2010; Selman, Harding, Gysels, Speck, \& Higginson, 2011; Cobb, Dowrick, \& Lloyd-Williams, 2012; Dose, Leonard, McAlpine, \& Kreitzer, 2014; Counted, Possamai, \& Meade, 2018). As for the fact, the primary component of spirituality is related to the deity concept or the relation among humans and God or a higher creature (Mohan \& Uys, 2006; Edwards et al., 2010; Dose et al., 2014). Besides, "purpose and meaning" are also the fundamental aspects of spirituality (Howden, 1992; Vachon et al., 2009). The relationship between human and God or a higher creature leads them to a directed life purpose, primarily in solving life issues, as well as become the control when they face the problems (Babarin, 1993; Hefti, 2011; Johnson et al., 2011; Counted, Possamai, \& Meade, 2018). The spiritual dimension in this research refers to Howden's (1992) study. It contains four components, namely (1) meaning of purpose, (2) innerness, (3) interconnectedness, and (4) transcendence.

Spirituality is an exciting issue discussed in Indonesia, considering Indonesia is a very plural country with a variety of cultures. Spirituality is one of the hugely influential cultural components. Ethnographic study results suggest that Indonesian culture is very complex and spread from Sabang to Merauke (Koentjaraningrat, 1976). Indonesia has around 1,340 tribes, with 300 ethnic groups spread across all parts of its territory. Indonesia is also a multi-faith country that recognizes six religions, namely; Islam, Christianity, Catholicism, Hinduism, Buddhism, and Confucianism (Denura, 2017).

Although there have been studies examining the relationship between spirituality and empathy, they have shown mixed results. Some indicate positive relationship (Lal et al., 2020; Moloney \& Gair, 2015; Stewart \& Lawrence, 2020) and others are negative (Markstrom et al., 2010; Stewart et al., 2018). This difference in results is due to several factors including culture. In addition, there is no similar research in Indonesia, so to close this gap this research aims to: (1) test the measurement model on the spirituality and empathy constructs, along with their dimensions, (2) test the spirituality effect on empathy and vice versa. The results of this research suggest future research to place a spiritual approach as the basis of counseling in universities during the Covid-19 pandemic and as an anticipatory to face other critical situations.

\section{Method}

The samples in this study were 1004 respondents from 65 universities in East Java, Indonesia. According to the membership data on East Java Central Bureau of Statistics, there are 326 universities in East Java. Hair, et. al, (2014) recommend the sample size for the endogenous construct model with two directions is 52 , at minimum, with a significance level of $0.05,80 \%$ statistic power, and R2 $=0.25$ minimum. Thus, the sample size in this research is more than the minimum size required. 
The research data were obtained during the Covid-19 pandemic. The students were in a physical distancing situation; thus, they were obligated to learn from home. The data was gathered online from April 26th to May 3rd, 2020. The respondents were invited to fill an online questionnaire measuring spirituality, level of empathy, and demographics. All of them were agreed to be research subjects. Their participation was voluntary without any reward, class credit, or monetary reward. Ethical approval was obtained through lecturers and University Institutional Review Board.

The questionnaire consisted of a socio-demographic section and two widely-used self-report instruments. Those instruments were chosen due to their psychometric properties, robust validity, and reliability. The empathy dimensions were measured through an Indonesia version of the Interpersonal Reactivity Index (IRI) with28-items questionnaire divided into four subscales. IRI subscales were first developed by Davis in 1980. IRI evaluates emotional empathy and the cognitive domain of empathy (Stehlíková \& Valihorová, 2016). It consists of (1) "Empathic Concern" (IRI-EC) subsists of 7 items that measure sympathetic and apprehension feeling toward other people's misfortune; (2) "Personal Distress" (IRI-PD) consists of 8 items that evaluate anxiety and worry on the interpersonal situation; (3) "Perspective Taking" (IRI-PT) subsists of 6 items of the natural tendency to judge from other people's perspective; and (4) "Fantasy" (IRI-FS) consists of 7 items that assess the respondents' tendency to sense fictional character from movies, dramas, and books. Respondents were asked to show how each item represented them on a 4-point Likert scale from 1 (very not corresponding) to 4 (very corresponding). In this research, the Cronbach's Alpha for IRI is 0.778 , as shown in Table 1.

On the other hand, the spiritual dimensions were assessed by the Indonesian version of the Spirituality Assessment Scale (SAS). SAS was first established by Howden, 1992. It is a 28-items questionnaire divided into four subscales. The SAS subscales measure: (1) "Meaning of purpose" (SASMP), 4 items. (2) "Innerness" (SAS-IN), 9 items. (3) "Interconnectedness" (SAS-IT), 9 items, and (4) "Transcendence" (SAS-TS), 6 items. The respondents were asked to show how each item represented them on a 4-point Likert scale, from 1 (very not corresponding) to 4 (very corresponding). In this research, the Cronbach's Alpha for SAS subscales is 0.844 , as presented in Table 1. In addition to the measurement model, the structural model puts each dimension as the latent variable. The obtained data was analysed using Smart PLS version 3.0.

\section{Results and Discussions}

The measurement model is presented in Figure 1. According to the Smart PLS calculation, all items with lower than 0.6 loading factors were deleted from the model. Based on the parameters in Table 1 and Table 2, the measurement model validity and reliability can be analyzed. For the validity analysis, convergent and discriminant validity were used. The convergent validity was based on the Average Variance Extracted (AVE).

The AVE values for most of the constructs were above 0.5. Thus, the measurement model has good convergent validity. Additionally, the discriminant validity was analyzed by using numbers in Table 2 . The diagonally bold numbers are the square roots of the AVE. Those numbers are higher than other list numbers. In other words, this model has good discriminant validity.

Internal consistency and composite reliability were used as the reliability analysis in this research. The internal consistency was explained through Cronbach's Alpha. The ideal score of internal consistency with Cronbach's Alpha is more than 0.7. However, according to (Hair et al., 2014), for explanatory research, items or constructs with loading factor or Cronbach's Alpha or composite reliability of $0.6-0.7$ can be used in the model. Table 1 shows the Cronbach's Alpha on IRI-EC and IRI-PD dimensions were below 0.6. However, the composite reliability of all dimensions was above 0.6. Therefore, the measurement model has good composite reliability but some dimensions are lacking on internal consistency reliability. Generally, this measurement model is valid and reliable for spirituality and empathy constructs. 
Table 1. Validity and Reliability

\begin{tabular}{lccc}
\hline \multicolumn{1}{c}{ Dimensions } & $\begin{array}{c}\text { Cronbach's } \\
\text { Alpha }\end{array}$ & $\begin{array}{c}\text { Composite } \\
\text { Reliability }\end{array}$ & $\begin{array}{c}\text { Average Variance Extracted } \\
\text { (AVE) }\end{array}$ \\
\hline EMPATHY (IRI) & 0,778 & 0,831 & 0,312 \\
\hline $\begin{array}{l}\text { Empathic Concern (IRI- } \\
\text { EC) }\end{array}$ & 0,472 & 0,791 & 0,654 \\
\hline Fantasy (IRI-FS) & 0,699 & 0,815 & 0,524 \\
Personal Distress (IRI-PD) & 0,388 & 0,763 & 0,618 \\
\hline $\begin{array}{l}\text { Perspective Taking (IRI- } \\
\text { PT) }\end{array}$ & 0,613 & 0,795 & 0,565 \\
\hline Innerness (SAS-IN) & 0,715 & 0,840 & 0,637 \\
\hline $\begin{array}{l}\text { Interconnectedness (SAS- } \\
\text { IT) }\end{array}$ & 0,655 & 0,793 & 0,490 \\
\hline $\begin{array}{l}\text { Meaning of Purpose (SAS- } \\
\text { MP) }\end{array}$ & 0,703 & 0,836 & 0,630 \\
\hline Transcendence (SAS-TS) & 1,000 & 1,000 & 1,000 \\
\hline SPIRITUALITY (SAS) & 0,844 & 0,876 & 0,379 \\
\hline
\end{tabular}

Table 2. Discriminant Validity

\begin{tabular}{lrccccccccc}
\hline & Empathy & $\begin{array}{c}\text { IRI- } \\
\text { EC }\end{array}$ & $\begin{array}{c}\text { IRI- } \\
\text { FS }\end{array}$ & $\begin{array}{c}\text { IRI- } \\
\text { PD }\end{array}$ & $\begin{array}{c}\text { IRI- } \\
\text { PT }\end{array}$ & $\begin{array}{c}\text { SAS- } \\
\text { IN }\end{array}$ & $\begin{array}{c}\text { SAS- } \\
\text { IT }\end{array}$ & $\begin{array}{c}\text { SAS- } \\
\text { MP }\end{array}$ & $\begin{array}{c}\text { SAS- } \\
\text { TS }\end{array}$ & Spirituality \\
\hline Empathy & 0,559 & & & & & & & & & \\
IRI-EC & 0,737 & 0,809 & & & & & & & & \\
IRI-FS & 0,744 & 0,404 & 0,724 & & & & & & & \\
IRI-PD & 0,695 & 0,444 & 0,323 & 0,786 & & & & & & \\
IRI-PT & 0,759 & 0,408 & 0,337 & 0,431 & 0,752 & & & & & \\
SAS-IN & 0,463 & 0,382 & 0,228 & 0,313 & 0,446 & 0,798 & & & & \\
SAS-IT & 0,508 & 0,453 & 0,241 & 0,364 & 0,461 & 0,559 & 0,700 & & & \\
SAS-MP & 0,451 & 0,345 & 0,197 & 0,336 & 0,461 & 0,610 & 0,621 & 0,794 & & \\
SAS-TS & 0,351 & 0,250 & 0,165 & 0,235 & 0,378 & 0,417 & 0,371 & 0,439 & 1,000 & \\
Spiritulaity & 0,564 & 0,459 & 0,267 & 0,397 & 0,548 & 0,843 & 0,833 & 0,865 & 0,585 & 0,615 \\
\hline
\end{tabular}

The results of the structural model analysis show various things. First, VIF Inner Model: Spirituality - Empathy is 1.000, while Empathy - Spirituality is 1.000. All of the VIF scores are lower than 5, indicating that there is no co linearity issue in the structural model. Second, Table 3 shows the outer path coefficient of the constructs and their dimensions. Empathy has value toward empathy concern (IRI-EC), fantasy (IRI-FS), personal distress, and perspective-taking of $0.737,0.744,0.695$, and 0.759 , respectively. On the other hand, spirituality has value upon innerness (SAS-IN), interconnectedness (SAS-IT), the meaning of purpose (SAS-MP), and transcendence (SAS-TS) of $0.843,0.833,0.865$, and 0.585, respectively. The highest score is in spirituality toward the meaning of purpose $(0.865)$, while the lowest score is toward transcendence (0.585). All of the dimensions obtain loading factors above 0.6. Additionally, all of the constructs have path coefficient scores with a t-test of more than 1.96 and $p$-Value $=0.000$. This shows that each construct is significantly related to its dimensions.

The results of hypothesis testing are shown in Table 4. The path coefficient of spirituality toward empathy is 0.654 with $\mathrm{t}$-Test $=19.255$ and $\mathrm{p}$-Value $=0.000$. Thus, $\mathrm{H} 0$ is rejected and $\mathrm{H} 1$ is accepted. There is a positive and significant effect on spirituality toward empathy. Conversely, there is also a positive and substantial effect on empathy toward spirituality with a path coefficient of 0.654 (shown in Figure 2 and Figure 3). Therefore, $\mathrm{H} 2$ is also accepted. Spirituality and empathy have positive and significant reciprocal effects. 
Table 3. Outer Path Coefficient

\begin{tabular}{lclcccc}
\hline Construct & & \multicolumn{1}{c}{ Dimension } & $\begin{array}{c}\text { Path } \\
\text { Coefficient }\end{array}$ & t-Statistics & p-Values & Result \\
\hline Empathy & IRI-EC & Empathic Concern & 0,737 & 37,779 & 0,000 & Significant \\
& IRI-FS & Fantasy & 0,744 & 30,591 & 0,000 & Significant \\
& IRI-PD & Personal Distress & 0,695 & 28,777 & 0,000 & Significant \\
& IRI-PT & Perspective Taking & 0,759 & 37,171 & 0,000 & Significant \\
Spirituality & SAS-IN & Innerness & 0,843 & 78,756 & 0,000 & Significant \\
& SAS-IT & Interconnectedness & 0,833 & 59,568 & 0,000 & Significant \\
& SAS-MP & Meaning of Purpose & 0,865 & 84,060 & 0,000 & Significant \\
& SAS-TS & Transcendence & 0,585 & 19,188 & 0,000 & Significant \\
\hline
\end{tabular}

Table 4. Hypotesis Testing

\begin{tabular}{lcrrl}
\multicolumn{1}{c}{ Hypotesis } & $\begin{array}{c}\text { Path } \\
\text { Coefficient }\end{array}$ & t-Statistics & p-Values & Result \\
\hline H1 : Spitituality -> Empathy & 0,654 & 19,255 & 0,000 & Supported \\
\hline H2 : Empathy -> Spirituality & 0,654 & 19,255 & 0,000 & Supported \\
\hline
\end{tabular}

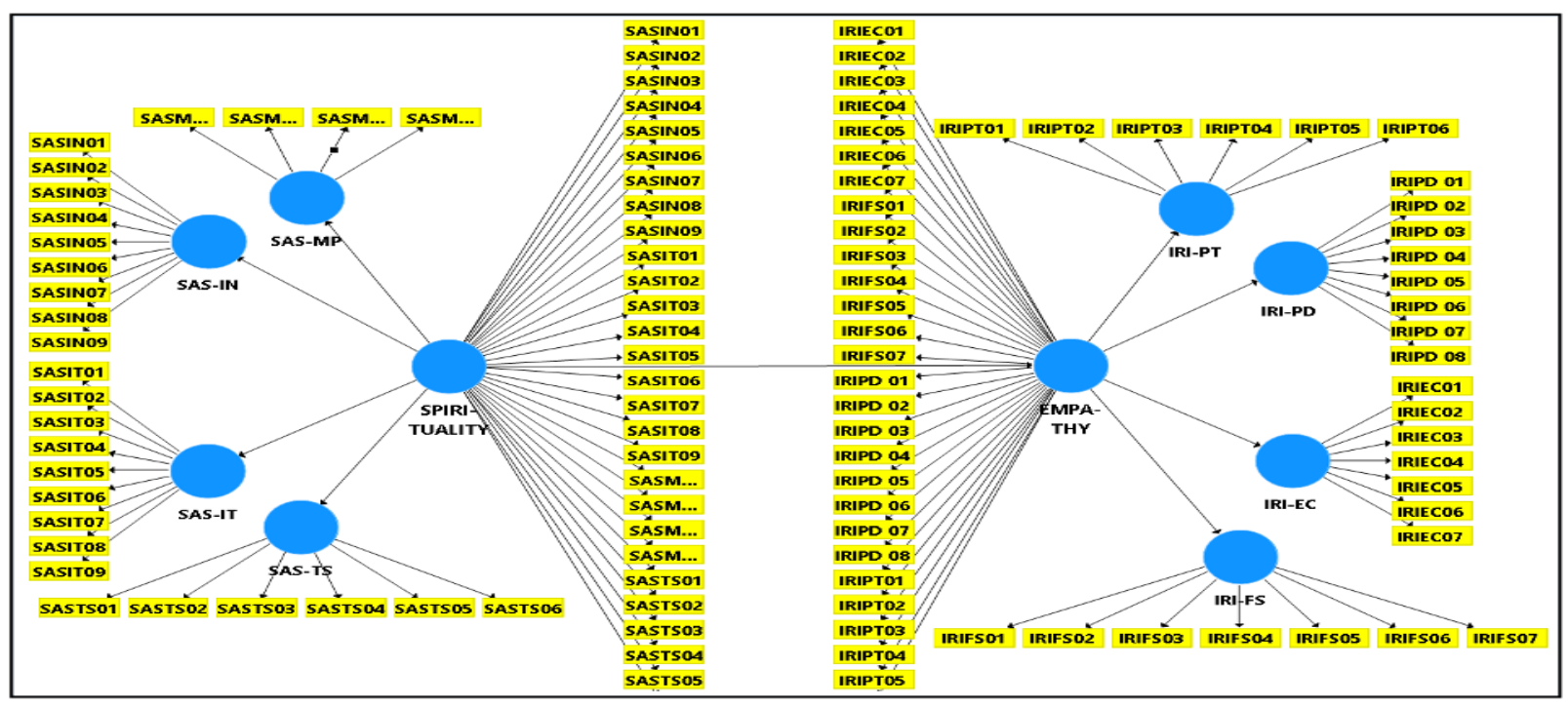

Figure 1. Research Model

This study exhibited a powerful, positive, and significant relationship between spirituality and empathy. The findings suggested that each construct possesses an essential effect on its dimensions. These results support the findings from previous research, while, against some other research findings. 


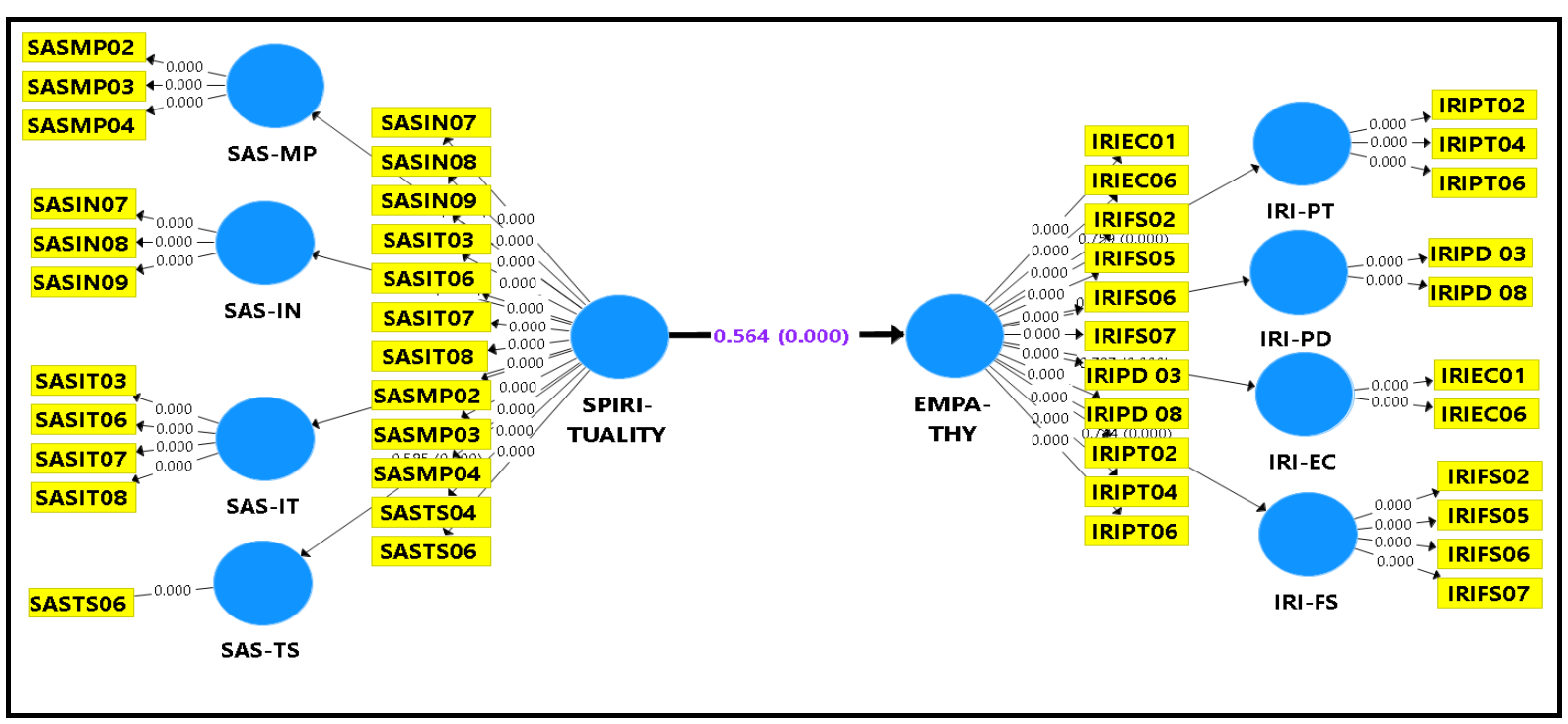

Figure 2. Spirituality Affects Empathy

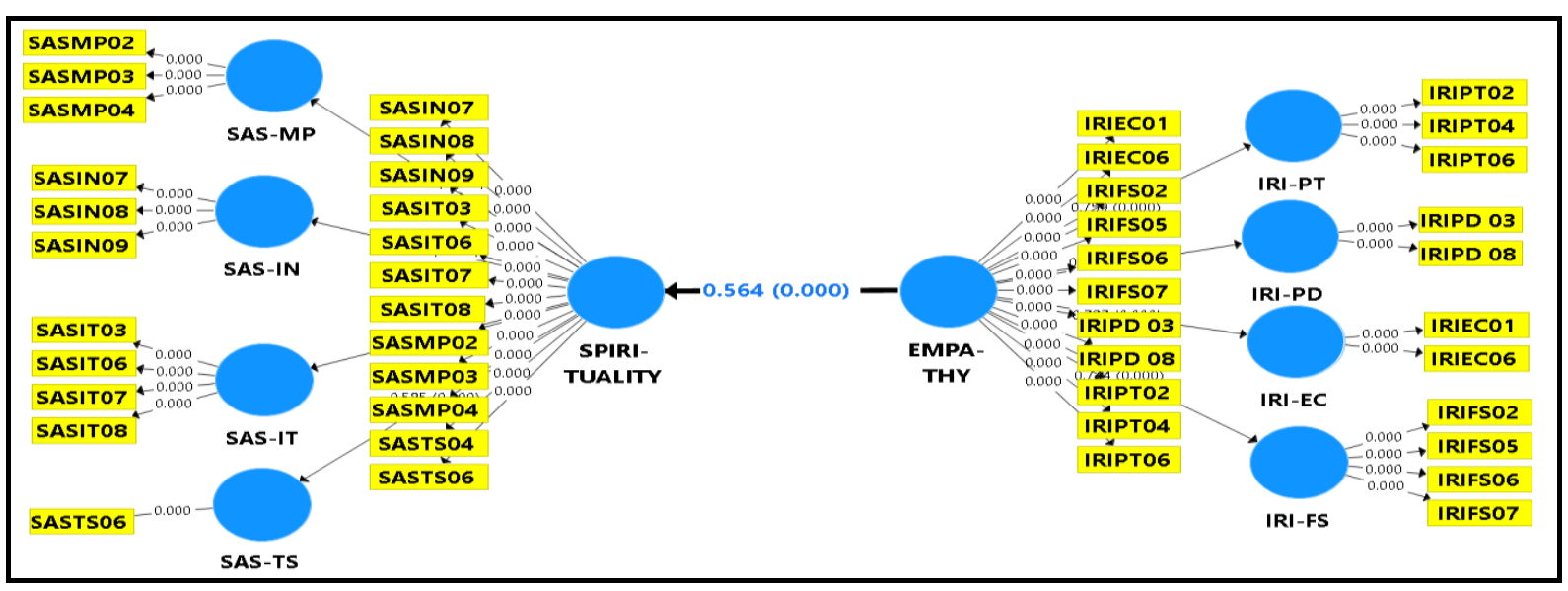

Figure 3. Empathy Affects Spirituality

The findings contradict a study conducted by Stewart, Lawrence, and Burg (2018) on 233 students from three universities in Central Florida who that found spiritual dimensions did not affect empathy. However, spirituality has various definitions. Similarly, this study also challenges the investigation done by Stewart et al. (2018), who used core spirituality, spiritual perspective, spiritual application, and spiritual acceptance dimensions. Those spiritual dimensions are different from the ones used in this research, referring to Howden (1992). It consists of four dimensions, namely (1) meaning of purpose, (2) innerness, (3) interconnectedness, and (4) transcendence. Meaning of purpose is defined as the process to search or find an occasion that transfers a meaningful feeling as hope or life purpose. Meanwhile, innerness refers to the process of discovering integrity, identity, and strength. Besides, interconnectedness is the attachment with other people and all life, the harmony on oneself and other people, as well as the feeling of consolidating with the universe and the higher creatures. The last dimension, transcendence, means the ability to go beyond the general physical and psychological skill.

The dimensions mentioned by Stewart et al., (2018) and Howden (1992) have many differences, primarily on the meaning of purpose and interconnectedness that do not exist in Stewart et al., (2018). On the other hand, other research concludes that those two are the main components of spirituality that strongly and positively affect designated counselor students' empathy (Giordano et al., 2014). Therefore, the contradicting findings are caused by the different spirituality definition used. 
Our findings also reverse a study carried out by Markstrom et al., in 2010. Their results conveyed that spirituality did not affect empathy. The spirituality was defined as religious attendance, generally related to someone's habit to perform religious rituals. In its measurement, one of the questions was "How often do you attend religious services?" The respondents were asked to choose a response based on their intensity to attend religious services (Markstrom et al., 2010; Watson et al., 1984).

In cases in the pandemic covid-19 era in Indonesia, even though there were rules about social restrictions, there were still religious activities carried out in places of worship. Even online media reported covid-19 patients who were supposed to carry out the command of independent isolation instead of leading religious activities at the worship (Sihombing, 2020). Though studies have proven that this crowd of people has the potential to increase Covid-19 transmission to others (L. Liu, 2020), in addition, the government's recommendations about physical distancing and large-scale social restrictions also clearly prohibit it. This phenomenon is contrary to the definition of spirituality (Howden, 1992). Apart from that, the definition of spirituality is not related to the routine of religious activities. in this case, the aspect of interconnectedness was also ignored. Interconnectedness in spirituality invites humans to unite with all components of life and nature, maintaining the survival of humanity and the universe, not the other way around.

This spiritual definition is different from the one used in this research. This research defines spirituality as the relationship between humans and God or higher creatures. Thus, the evaluation also refers to that definition. Therefore, the research findings contradict each other.

In addition to contradicting some research, our findings also support some other previous works. For instance, the findings support research conducted by King, Mara, Decicco, King, and Mara (2012) who mentioned that spirituality as intelligence significantly affects empathy. Other spirituality constructs that directly and essentially impact empathy is religious commitment. It is strongly correlated to two spiritual dimensions, namely meaning of purpose and innerness (Hardy et al., 2012).

Besides, the findings of this study also support research conducted by Huber and MacDonald (2012) who reveals positive and critical relation among non-religious spiritual cognition, religiosity, and spiritual experiences. Their findings also portray that spiritual experiences and awareness strongly interact with altruism. The regression analysis acknowledges that non-religious spiritual cognition and spiritual experiences are the most robust predictor for empathy and altruism. Pavlovich and Krahnke (2012) also mention that empathy accelerates altruism. On the other hand, altruism is similarly defined with interconnectedness in this research. Empathy improves interconnectedness through many neural pathways, unconsciously. If someone shares with others, happiness and harmony feelings are activated. This pushes personal freedom. Consequently, empathy is the key to coherently discover interconnectedness (Pavlovich \& Krahnke, 2012).

Other research also mentions that spirituality is closely related to personal accomplishment. In the study also mentioned that high empathy affects emotion exhaustion (Lal et al., 2020). Another negative effect of empathy is the tendency for guilt. Guilt is a moral emotion often seen as a negative trait. On the other hand, the study results show that the individual has a tendency to think, feel, and act in a more ethical manner (Baggaley, 2012). Other studies suggest that cognitive empathy and emotional empathy are negatively correlated with the trait of Callous-Unemotional (CU) (Lethbridge et al., 2017). In general, empathy is a positive emotion that is important to develop. However, it is important to consider other factors that have a negative impact. So that the relevance of empathy needs to be considered in terms of levels and usefulness. Form \& Kaernbach (2018) states that having many social relationships with others does not always have a good effect on individuals, including efforts to increase creativity.

In this context empathy can actually create new problems if it is not accompanied by spirituality, especially in the current crisis period in the Covid-19 pandemic situation. So that spiritual care is needed here because spiritual care is highly recommended to improve the psychological condition of individuals (Moloney \& Gair, 2015). Crisis situations like the current pandemic are causing deep trauma to Covid-19 victims and the general public. Regardless of the transmission factor, this Covid-19 infection causes profound physical and psychological complications. Lee, et al. (Landry et al., 2020) in previous experience when the community faced the H7N9 epidemic, reported that patients infected with H7N9 (influenza A) had long-term pulmonary defects and severe psychological disorders even two years after repatriation. Especially at this time the conditions faced are no longer epidemic but pandemic, so that it causes more 
severe and widespread impact. A similar epidemic occurred in 2003. Chan et al. (Landry et al., 2020) in the case of Severe Acute Respiratory Syndrome (SARS) states that SARS is another transmission in the coronavirus family. The results showed that one year after surviving, individual victims of SARS continued to experience increased levels of stress, depression and anxiety.

In dealing with these crisis situations high awareness from the community is needed to support each other in the success of the physical distancing movement and also maintain and even improve prosocial attitudes through healthy empathy. However the impact of the Covid-19 pandemic is not only upon Covid-19 patients but also on the entire community. In the context of efforts to improve students' psychological conditions, efforts made so far have been through counseling interventions at the university. The approaches used are western counseling approaches in which the power of spirituality is not included. Another weakness of Western counseling is not being able to accommodate cultural interests, social values, collective relationships, and spiritual views. Whereas at present, cultural factors are determinants of problem solving holistically (Bauman et al., 2019; Cameron, 2010; Wendt \& Gone, 2016), moreover researchers agree that spirituality in the cultural context acts as a human control when facing various problems (Babarin, 1993; Counted et al., 2018; Hefti, 2011; Johnson et al., 2011). Research even mentions that collective relations through strengthening national identity are fundamental to be carried out for the spirit of unity (Mashuri \& Zaduqisti, 2014). Coping strategies are also recommended to increase relationship satisfaction with dyadic empathy in a group (Levesque et al., 2014). Community cohesiveness is needed in one unit to combat this pandemic condition.

National and local branding is very important to be played by every students, both foreign and original (Park et al., 2016). The assumption of recent study was also made concerning the exploration of youth's image of the axiological world and the valuing orientations manifested by them, that make it possible to learn the way(s) rooted in culture and experience, in which learners understand themselves, Others and the world (Ogrodzka-Mazur \& Saukh, 2019).

Referring to the results of Mashuri \& Zaduqisti (2014) research, it is important to arouse national identity as a strategy for dealing with multicultural and religious Indonesian society. The nation's motto is the next concern in research. Bhinneka Tunggal Ika as the nation's motto has deep therapeutic elements to arouse the collective awareness of the Indonesian people. Constitutionally, Unity in Diversity is a symbol of the Indonesian state which has been regulated in article 36A of the 1945 Constitution which reads "The State is Garuda Pancasila with the motto Bhinneka Tunggal Ika". Bhinneka Tunggal Ika's writings are clearly displayed on the feet of Garuda Birds (Undang-Undang Dasar, 1945). The values in this national motto are explained in the Book of Sutasoma by Mpu Tantular, which is the term our first Unity in Diversity appears. The two key concepts contained in the motto are spiritual and multicultural. This is very relevant to the findings of this study, where spirituality with empathy has a reciprocal influence, meaning humans have a reciprocal relationship both with God and with other humans in spiritual and multicultural contexts. Conceptually local spiritual values are very important to be internalized so that they can be used as an approach in solving the problem of psychological impact covid-19 holistically.

The spiritual dimensions, such as the meaning of purpose, innerness, interconnectedness, and transcendence in the nation's motto should be further researched and studied to be a unique counseling construct from Indonesia. Its relevance is to be used as a counseling approach in universities to help students undergo crisis with high humanitarian attitudes since other crises like Covid-19 may appear in different contexts and scope.

\section{Conclusions}

This study has attempted to unveil the relationship between spirituality and empathy. Our findings suggest that spirituality has a direct and significant effect on empathy, while, each construct is significantly related to their dimensions. Accelerating someone's spiritual condition that is related to God, affects human-to-human relations, through empathy. The balance between human vertical (with God) and horizontal (with another human) relationship is proven in this research. Fundamentally, humans need spiritual and socio-multicultural relations. It becomes a challenge for counseling institutions in the universities to allow students to internalize spiritualism in themselves to realize healthy empathy. 
This study employed an explanatory research design in capturing data from the participants. Our findings suggest predictions of the structural model of spirituality and empathy enacted by students in the Covid-19 outbreak. Albeit its attempts to unveil the phenomena, the study is open for some limitations, and thus, encourages future researchers to explore: (1) internal consistency reliability or Cronbach's Alpha on several dimensions, namely Empathic Concern (IRI-EC) and Personal distress (IRI-PD), (2) moderator variables namely gender, age, respondent status in the Covid-19 situation, and the respondent's area of origin, and (3) new counseling constructs using spiritual dimensions as one of its main strengths along with local excellence in a country.

\section{Acknowledgments}

This research was supported by the Institute for Research and Community Services, Nahdlatul Ulama University of Surabaya, Indonesia with contract number 362.26/UNUSA/Adm-LPPM/V/2020. Then, we express our sincere thanks to the Center for Scientific Publication, State University of Malang, for the translation and proofreading services.

\section{References}

Albers, G., Echteld, M. A., De Vet, H. C. W., Onwuteaka-Philipsen, B. D., Van Der Linden, M. H. M., \& Deliens, L. (2010). Content and spiritual items of quality-of-life instruments appropriate for use in palliative care: A review. Journal of Pain and Symptom Management, 40(2), 290-300. https://doi.org/10.1016/j.jpainsymman.2009.12.012

Azanella, L. A. (2020, April 13). Luthfia Ayu Azanella. Kompas.Com. https://www.kompas.com/tren/read/2020/04/13/110821765/penolakan-jenazah-pasien-covid-19mengapa-bisa-terjadi? page $=2$

Babarin, O. (1993). Coping and Resilience: Exploring the Inner Lives of African American Children. Journal of Black Psychology 4(19): 478-492.

Baggaley, J. (2012). Harmonizing global education: From Genghis Khan to Facebook. Harmonizing Global Education: From Genghis Khan to Facebook, October, 1-197. https://doi.org/10.4324/9780203817636

Bauman, S. S. M., Acker-Hocevar, M., Talbot, D. L., Visaya, A., Valencia, M., \& Ambriz, J. (2019). Exploring and Promoting the College Attendance and Success of Racial/Ethnic Minority Students. Journal of Multicultural Counseling and Development, 47(1), 37-48. https://doi.org/10.1002/jmcd.12119

Cameron, L. (2010). Using the arts as a therapeutic tool for counselling - An Australian Aboriginal perspective. Procedia - Social and Behavioral Sciences, 5, 403-407. https://doi.org/10.1016/j.sbspro.2010.07.112

Cobb, M., Dowrick, C., \& Lloyd-Williams, M. (2012). What can we learn about the spiritual needs of palliative care patients from the research literature? Journal of Pain and Symptom Management, 43(6), 1105-1119. https://doi.org/10.1016/j.jpainsymman.2011.06.017

Counted, V., Possamai, A., \& Meade, T. (2018). Relational spirituality and quality of life 2007 to 2017 : An integrative research review. Health and Quality of Life Outcomes, 16(1), 1-18. https://doi.org/10.1186/s12955-018-0895-X

Davis, M. H. (1980). Measure: INTERPERSONAL REACTIVITY INDEX (IRI) - measures empathy. JSAS Catalog of Selected Documents in Psychology, 10(1980), 85.

Denura, F. (2017, April 26). Di Indonesia Ada 1.340 Suku Bangsa dan 300 Kelompok Etnik. Netralnews. Com.

https://www.netralnews.com/news/rsn/read/71459/di.indonesia.ada.1340.suku.bangsa.dan.300.ke lompok.etnik

Dose, A. M., Leonard, B., McAlpine, C. P., \& Kreitzer, M. J. (2014). The meaning of spirituality at the end of life. Journal of Hospice and Palliative Nursing, 16(3), 158-164. https://doi.org/10.1097/NJH.0000000000000041

Edwards, A., Pang, N., Shiu, V., \& Chan, C. (2010). Review: The understanding of spirituality and the potential role of spiritual care in end-of-life and palliative care: A meta-study of qualitative research. Palliative Medicine, 24(8), 753-770. https://doi.org/10.1177/0269216310375860

Farrelly, D., Moan, E., White, K., \& Young, S. (2015). Evidence of an alternative currency for Altruism in Laboratory-Based Experiments. Europe's Journal of Psychology, 11(1), 100-111. 
https://doi.org/10.5964/ejop.v11i1.855

Form, S., \& Kaernbach, C. (2018). More is not always better: The differentiated influence of empathy on different magnitudes of creativity. Europe's Journal of Psychology, 14(1), 54-65. https://doi.org/10.5964/ejop.v14i1.1432

Giordano, A. L., Prosek, E. A., \& Lankford, C. T. (2014). Predicting Empathy: The Role of Religion and Spirituality. Journal of Professional Counseling: Practice, Theory \& Research, 41(2), 53-66. https://doi.org/10.1080/15566382.2014.12033938

Hair, J., Hult, G. T. M., Ringle, C., \& Sarstedt, M. (2014). A Primer on Partial Least Squares Structural Equation Modeling (PLS-SEM). SAGE. https://doi.org/http://hdl.handle.net/1959.13/1063732

Halfpenny, C. C., \& Amelia, J. L. (2020). Humor Styles and Empathy in Junior-School Children. Europe's Journal of Psychology, 16(1). https://doi.org/https://doi.org/10.5964/ejop.v16i1.1934

Hardy, S. A., Walker, L. J., Rackham, D. D., \& Olsen, J. A. (2012). Religiosity and adolescent empathy and aggression: The mediating role of moral identity. Psychology of Religion and Spirituality, 4(3), 237248. https://doi.org/10.1037/a0027566

Hefti, R. (2011). Integrating religion and spirituality into mental health care, psychiatry and psychotherapy. Religions, 2(4), 611-627. https://doi.org/10.3390/rel2040611

Howden, J. W. (1992). Development and Psychometric Characteristics of The Spiritual Assesment Scale (Issue December). TEXAS WOMAN'S UNIVERSITY.

Huber, J. T., \& MacDonald, D. A. (2012). An investigation of the relations between altruism, empathy, and spirituality. Journal of Humanistic Psychology, 52(2), 206-221. https://doi.org/10.1177/0022167811399442

Johnson, K. S., Tulsky, J. A., Hays, J. C., Arnold, R. M., Olsen, M. K., Lindquist, J. H., \& Steinhauser, K. E. (2011). Which domains of spirituality are associated with anxiety and depression in patients with advanced illness? Journal of General Internal Medicine, 26(7), 751-758. https://doi.org/10.1007/s11606-011-1656-2

King, D. B., Mara, C. A., Decicco, T. L., King, D. B., \& Mara, C. A. (2012). Connecting the Spiritual and Emotional Intelligences: Confirming an Intelligence Criterion and Assessing the Role of Empathy. 31(1), 11-20. https://doi.org/http://dx.doi.org/10.24972/ijts.2012.31.1.11

Koentjaraningrat. (1976). "Manusia dan Kebudayaan Di Indonesia." In Djambatan (p. 390). Djambatan. https://doi.org/10.1016/s0044-8486(97)00050-1

Lal, A., Tharyan, A., \& Tharyan, P. (2020). The prevalence, determinants and the role of empathy and religious or spiritual beliefs on job stress, job satisfaction, coping, burnout, and mental health in medical and surgical faculty of a teaching hospital: A cross-sectional survey. Revue de Medecine Interne, 41(4), 232-240. https://doi.org/10.1016/j.revmed.2019.12.005

Landry, M. D., Geddes, L., Moseman, A. P., Lefler, J. P., Raman, S. R., \& Wijchen, J. van. (2020). Early Reflection on the Global Impact of COVID19, and Implications for Physiotherapy. Physiotherapy. https://doi.org/10.1016/j.physio.2020.03.003

Lee, A., \& Morling, J. (2020). COVID19 - The need for Public Health in a time of emergency. Public Health, $P G$-. https://doi.org/https://doi.org/10.1016/j.puhe.2020.03.027

Lethbridge, E. M., Richardson, P., Reidy, L., \& Taroyan, N. A. (2017). Exploring the relationship between callous-unemotional traits, empathy processing and affective valence in a general population. Europe's Journal of Psychology, 13(1), 162-172. https://doi.org/10.5964/ejop.v13i1.1179

Levesque, C., Lafontaine, M. F., Caron, A., Lyn Flesch, J., \& Bjornson, S. (2014). Dyadic empathy, dyadic coping, and relationship satisfaction: A dyadic model. Europe's Journal of Psychology, 10(1), 118-134. https://doi.org/10.5964/ejop.v10i1.697

Liu, C., Wu, C., Zheng, X., Zeng, F., Zhu, F., Gan, X., \& Huang, Y. (2020). ScienceDirect Clinical features and multidisciplinary treatment outcome of COVID-19 pneumonia : A report of three cases. Journal of the Formosan Medical Association, April, 1-8. https://doi.org/10.1016/j.jfma.2020.04.008

Liu, L. (2020). Emerging study on the transmission of the Novel Coronavirus ( COVID-19) from urban $\begin{array}{llll}\text { perspective: } & \text { evidence from China. Cities, 103(April), } 102759 .\end{array}$ https://doi.org/10.1016/j.cities.2020.102759

Markstrom, C. A., Huey, E., Stiles, B. M., \& Krause, A. L. (2010). Frameworks of caring and helping in adolescence: Are empathy, religiosity, and spirituality related constructs? Youth and Society, 42(1), 5980. https://doi.org/10.1177/0044118X09333644

Mashuri, A., \& Zaduqisti, E. (2014). National identification and collective emotions as predictors of prosocial attitudes toward Islamic minority groups in Indonesia. Europe's Journal of Psychology, 10(2), 255- 
276. https://doi.org/10.5964/ejop.v10i2.707

Mohan, D. L., \& Uys, K. (2006). Towards living with meaning and purpose: Spiritual perspectives of people at work. SA Journal of Industrial Psychology, 32(1), 53-59. https://doi.org/10.4102/sajip.v32i1.228

Moloney, S., \& Gair, S. (2015). Empathy and spiritual care in midwifery practice: Contributing to women's enhanced birth experiences. Women and Birth, 28(4), 323-328. https://doi.org/10.1016/j.wombi.2015.04.009

Nelson, J. M. (2009). Psychology, Religion, and Spirituality. Springer. https://doi.org/10.1007/978-0-38787573-6

Ogrodzka-Mazur, E., \& Saukh, P. (2019). The social and cultural tendencies in the environment of contemporary youth. A Polish-Ukrainian comparative study of the structure of axiological reality. New Educational Review, 57, 63-74. https://doi.org/10.15804/tner.2019.57.3.05

Park, J. K., Kim, Y. D., \& DeMatteo, K. (2016). Nation branding through internationalization of higher education: A case study of African students in South Korea. New Educational Review, 45(3), $52-63$. https://doi.org/10.15804/tner.2016.45.3.04

Pavlovich, K., \& Krahnke, K. (2012). Empathy, Connectedness and Organisation. Journal of Business Ethics, 105(1), 131-137. https://doi.org/10.1007/s10551-011-0961-3

Pfattheicher, S., Nockur, L., Böhm, R., Sassenrath, C., \& Petersen, M. B. (2020). The emotional path to action: Empathy promotes physical distancing during the COVID-19 pandemic. PsyArXiv [Working Paper], $i, 1-8$. https://doi.org/10.31234/OSF.IO/Y2CG5

Riandi, A. P. (2020). Polisi: Motif Ferdian Paleka Bikin Konten Prank Sembako Sampah untuk Naikkan Subscriber. Kompas.Com. https://www.kompas.com/hype/read/2020/05/08/153826066/polisimotif-ferdian-paleka-bikin-konten-prank-sembako-sampah-untuk-naikkan?page=all

Rogers, C. R. (1956). The Necessary and Sufficient Conditions of Therapeutic Personality Change. Journal of Consulting Psychology, 21, 95-103.

Selman, L., Harding, R., Gysels, M., Speck, P., \& Higginson, I. J. (2011). The measurement of spirituality in palliative care and the content of tools validated cross-culturally: A systematic review. Journal of Pain and Symptom Management, 41(4), 728-753. https://doi.org/10.1016/j.jpainsymman.2010.06.023

Sihombing, R. F. (2020). Imam Positif COVID Nekat Pimpin Tarawih, Ini Kata Kemenag. Detiknews. https://news.detik.com/berita/d-5014105/imam-positif-covid-nekat-pimpin-tarawih-ini-katakemenag

Stehlíková, J., \& Valihorová, M. (2016). Possibilities of targeted development of empathy in teachers' undergraduate training. New Educational Review, 45(3), 186-198. https://doi.org/10.15804/tner.2016.45.3.15

Stewart, C., \& Lawrence, S. (2020). A multi-dimensional exploration of spirituality to empathy. Journal of Spirituality in Mental Health, 00(00), 1-24. https://doi.org/10.1080/19349637.2020.1732266

Stewart, C., Lawrence, S., \& Burg, M. A. (2018). The Relationship of Personality and Spirituality to Empathy. Journal of Empirical Theology, 31(1), 1-17. https://doi.org/10.1163/15709256-12341366

Undang-Undang Dasar. (1945). Amandemen Undang-undang Dasar Ngara Republik Indonesia. 4(1), 1-12.

Vachon, M., Fillion, L., \& Achille, M. (2009). A conceptual analysis of spirituality at the end of life. Journal of Palliative Medicine, 12(1), 53-59. https://doi.org/10.1089/jpm.2008.0189

Watson, P. J., Hood, R. W., Morris, R. J., \& Hall, J. R. (1984). Empathy, religious orientation, and social desirability. Journal of Psychology: Interdisciplinary and Applied, 117(2), 211-216. https://doi.org/10.1080/00223980.1984.9923679

Wendt, D. C., \& Gone, J. P. (2016). Integrating Professional and Indigenous Therapies: An Urban American Indian Narrative Clinical Case Study. Counseling Psychologist, 44(5), 695-729. https://doi.org/10.1177/0011000016638741 